\title{
EchoGéo
}

41 | 2017

Un état des lieux du Brésil en 2017

\section{Regional Inequalities in Brazil: Divergent Readings on Their Origin and Public Policy Design}

Simone Affonso da Silva

\section{(e) OpenEdition \\ Journals}

Electronic version

URL: https://journals.openedition.org/echogeo/15060

DOI: 10.4000/echogeo.15060

ISSN: 1963-1197

\section{Publisher}

Pôle de recherche pour l'organisation et la diffusion de l'information géographique (CNRS UMR 8586)

\section{Electronic reference}

Simone Affonso da Silva, "Regional Inequalities in Brazil: Divergent Readings on Their Origin and Public Policy Design", EchoGéo [Online], 41 | 2017, Online since 03 October 2017, connection on 31 July 2021. URL: http://journals.openedition.org/echogeo/15060; DOI: https://doi.org/10.4000/ echogeo.15060

This text was automatically generated on 31 July 2021.

EchoGéo est mis à disposition selon les termes de la licence Creative Commons Attribution - Pas d'Utilisation Commerciale - Pas de Modification 4.0 International (CC BY-NC-ND) 


\title{
Regional Inequalities in Brazil: Divergent Readings on Their Origin and Public Policy Design
}

\author{
Simone Affonso da Silva
}

\section{Divergent readings and propositions about regional inequalities in Brazil}

1 Brazil has been considered a country of great potential, but it also faces great challenges regarding its total sociospatial dimensions, facing serious social, political, economic, environmental, and spatial problems. For researchers such as Oliveira (2003), Brandão (2007), and Araújo (2007), these problems derive partly from our condition as an underdeveloped country or an "uncompleted" Nation State.

2 In this context, one of the most relevant aspects characterizing the country is spatial inequalities, notably the regional-related ones. Whichever the socioeconomic indicator used to assess them, they always follow the same macro-regional pattern: Brazil's North and Northeast areas have the worst rates, while its central area has intermediate rates, and the South and Southeast areas have the best rates, as shown in the following map (figure 1). Even though indicators have improved over the last few decades, spatial disparities remain. 
Figure 1 -Map - Human Development Index of Brazilian municipalities in 1991, 2000, and 2010

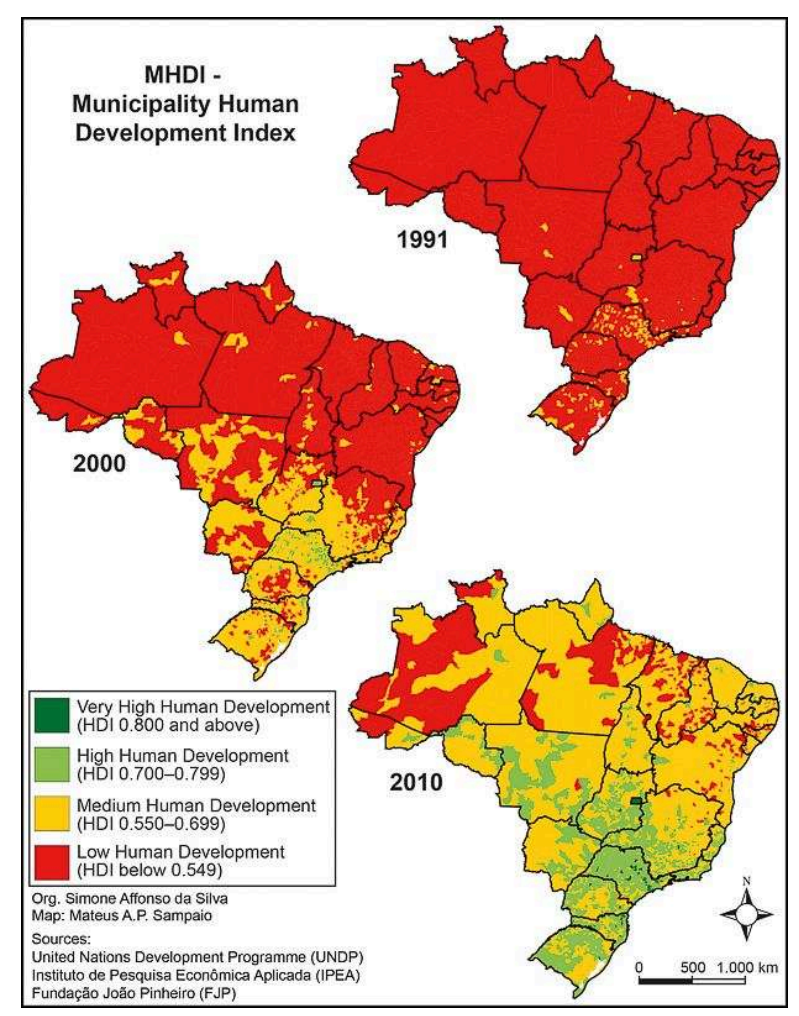

Source: http://www.atlasbrasil.org.br/2013/

Figure 2 - Human Development Index of Brazilian municipalities in 1991, 2000, and 2010

\begin{tabular}{|c|c|c|c|c|c|c|}
\hline \multirow[b]{2}{*}{ MHDI } & \multicolumn{2}{|l|}{1991} & \multicolumn{2}{|l|}{2000} & \multicolumn{2}{|l|}{2010} \\
\hline & $\begin{array}{c}\text { No. of } \\
\text { municipalities }\end{array}$ & $\%$ & $\begin{array}{c}\text { No. of } \\
\text { municipalities }\end{array}$ & $\%$ & $\begin{array}{c}\text { No. of } \\
\text { municipalities }\end{array}$ & $\%$ \\
\hline Very High Human Development & 0 & 0.0 & 1 & 0.0 & 44 & 0.8 \\
\hline High Human Development & 0 & 0.0 & 133 & 2.4 & 1,889 & 33.9 \\
\hline Medium Human Development & 248 & 4.5 & 2,383 & 42.8 & 3,275 & 58.8 \\
\hline Low Human Development & 5,317 & 95.5 & 3,048 & 54.8 & 357 & 6.4 \\
\hline $\begin{array}{l}\text { Org. Simone Affonso da Silva } \\
\text { \& Mateus A.P. Sampaio } \\
\text { Sources: } \\
\text { United Nations Development Programme (UNDP) } \\
\text { Instituto de Pesquisa Economica Aplicada (IPEA) } \\
\text { Fundação João Pisheiro (FJP) }\end{array}$ & & & & & & \\
\hline
\end{tabular}

Source: http://www.atlasbrasil.org.br/2013/

3 Since the consolidation of regional policies by the Brazilian public administration, in the mid-20th century, the debates over the regional problematic have fueled great controversy. Whether it is in the realm of academic production or the formulation of public policies, some factors stand out: the absence of a consensus over the definition and delimitation of regions; the conceptualization of regional inequalities; and the selection of indicators capable of assessing their dynamics, as well as the contrasting propositions regarding the actions that should be taken to mitigate regional inequality. Those controversies show how complex this subject is and alert us to the great challenges the country faces to fight the spatial inequalities that characterize it.

4 The fact that there are multiple interpretations on Brazil's regional inequalities is not a problem itself, but rather the lack of consensus on the determinants of regional 
inequalities and the very essence of actions that should be taken to mitigate them. This makes it difficult to formulate a more solid theory, one that can increase our understanding of the dynamics of Brazil's regional setting today, as substantially divergent theories and methodologies make it impossible to compare these researches or even view them as complementing each other. Furthermore, in a political and institutional environment marked by instability, discontinuity of public policies, departmentalization, fragmentation, and lack of cooperation between government offices, the lack of consensus over the regional problematic has contributed to the formulation of fragmented, unarticulated, conflicting, competing, and contradictory regional policies, jeopardizing the effectiveness and efficiency of Brazilian regional planning.

5 Next, we will present a debate on the origin of regional inequalities in Brazil and the essence of some government policies regarding regional development, based on documentary and bibliographical research, in order to problematize certain aspects of the role of regional inequalities in Brazil's development landscape.

\section{The Origin of Regional Inequalities}

6 The understanding of regional inequalities in Brazil is greatly based upon theoretical, methodological, and political aspects associated with the debates on socioeconomic disparities between the country's northeastern and southeastern parts, which are at the core of regional planning consolidation in the Brazilian State framework in the second half of the $20^{\text {th }}$ century.

7 In the document A Operação Nordeste ("Operation Northeast"), originally published in 1959, Furtado (2009a, p. 30-31) states that Brazil's regional inequalities arose in the first half of the $20^{\text {th }}$ century, in the framework of a process of economic and political integration of the regions, as a consequence of the country's industrialization. Until that point, the country's regions remained disarticulated, each experiencing a higher or lower level of growth according to the economic cycles that boosted them, with a fundamentally agricultural or extractive character.

8 According to Furtado (2009a, p. 31), the integration of Brazil's national market bore the seeds of the regional problematic, as it "(...) replicated the same geographic division of labor that would vitiate the development of the entire global economy, with its industrialized metropolises and its raw material-producing colonies." As a result of this pattern, as industrialization advanced, inequalities within Brazil would tend to increase, because the concurrence of a regionally-based industrial system and a set of dependent, subordinate primary-based economies tended to create exploitative economic relations (Ibid., p. 32). There is, therefore, a center-periphery analogy from the ECLAC's theoretical propositions ${ }^{1}$.

So in the document Uma Política de Desenvolvimento Econômico para o Nordeste ("An

Economic Development Policy for the Northeast"), published in 1959, Furtado (2009c, p. 83-130) points out that the wide disparities in income rates between the Northeast and the Midsouthern part of Brazil, as well as the slower growth rate of the northeastern economy, would tend to create two antagonistic systems in the country, which would jeopardize its national integration. The inadequacy of State-adopted macroeconomic and industrial policies would have contributed to exacerbate the 
problem, as the industrialized Midsouthern area was excessively favored (Ibid., p. 128 et seq.).

10 As Brandão (2013, p. 27) notes, Furtado believes the regional inequalities are within a process of structural malformation, which is at the core of underdevelopment, in which ecological, economic, social, and political dimensions intertwine. In terms of structures, Brazil's regional heterogeneity in the mid- $20^{\text {th }}$ century created a plethora of forms of underdevelopment generated in the scope of a historical process, Furtado argues (Menezes \& Filho, 2009, p. 268). This plethora of regions with different levels of development, great social heterogeneity and serious social problems remains until this day, the economist states (IBGE, 2003, p. 11).

11 In Cano's perspective (2002, p. 126), the problematic of regional imbalances in Brazil results from the historical development process of each region. The causes of regional imbalances were the feeble integration of a primary-based, exporting economy with the international market in parts of Brazil throughout its history, a fact that yielded lower growth and economic diffusion, and a substandard development of capitalist relations of production to the national periphery (Brazil, excluding the state of São Paulo, and including especially the North and Northeast) (Ibid., p. 257). For Cano:

(...) it wasn't the concentration of industrial (or agricultural or even tertiary) production in São Paulo what caused or intensified the backwardness and impoverishment in Brazil's poorest regions; but rather because, before 1930, the national economy was not integrated and each one of its regions had had its own specific economic trajectory and history, which gave them a cultural, demographic, and economic heritage - notably in the property and income structure -, defining their different degrees of absolute and relative poverty and their productive structures (Cano, 2008, p. 38).

12 Thus, the genesis of regional inequalities would have been between the $1880 \mathrm{~s}$ and 1930s, as a result of the uneven development of inter-regional capitalism, based on each region's relative autonomy and on different relations of production and economic dynamism (Cano \& Guimarães Neto, 1986, p. 169).

13 After the 1929 Crisis, those imbalances were intensified by the different economic growth rates in São Paulo and other regions (Cano, 2007, p. 299). "So São Paulo's lead in capitalist development tended to increase for reasons that, first and foremost, are related to the dynamics of that very pole, according to the cold capitalistic logic of industrial location" (Cano, 2008, p. 12).

It was not until the late 1960 s that a process of relative industrial deconcentration started to take place regionally, Cano states (2008). Still, the patterns of economic and social divergence remained in the 1980 s and even deepened in the 1990s, facing the grim effects of neoliberal policies (Ibid., p. 194-198).

Therefore, authors like Furtado and Cano understand the emergence of the Brazilian regional issue from a regional imbalance perspective, that is, viewing it from the growing socioeconomic disparities between the country's regions, which would have arisen in the framework of each region's internal dynamics, albeit related to differentiations in the spatial scope of the country's industrialization processes and the development of a national market.

16 According to Oliveira (2008, p. 163), the contradictions of capital reproduction and relations of production in each region, or at least in the country's two major regions, the sugar/livestock-cotton-producing Northeast and the coffee-producing/industrial 
Southeast, started to emerge as a conflict between those two regions, in which one was growing and the other remained stagnant. However, Oliveira (2008, p. 149) argues that the emergence of the regional issue must be understood from the perspective of regional division of labor, and not focused on regional imbalances.

Oliveira (2008, p. 201 et seq.) argues that the increase in regional disparities would have occurred in the context of the country's industrialization process, as a sign and a moment of national integration, in a dialectical movement that destroyed regional economies to concentrate and centralize capital in what is now the southeastern region, led by the state of São Paulo. Integration, understood as "a moment of the capital nationalization process," happens when regional economies, which were, until that point, directly connected to international markets, become controlled by the country's region that takes over the process of capitalist expansion within Brazilian territory.

Therefore, those disparities are the sign of the differential movement of accumulation in the relations between regions, in an overall process that led the system to a relentless "concentration of income, property, and power," with the "replacement of rural property-owning classes at the top of the power pyramid by new commercialindustrial bourgeois classes," where there was no possibility of a disruption in favor of working classes (Oliveira, 2003, p. 60 et seq.). In this sense, what was privileged was

(...) a concept of region based on the specificity of capital reproduction, on the forms the accumulation process takes, on the unique class structure of these forms and, hence, also on the forms of class struggle and social conflict in a more general scale (Oliveira, 2008, p. 145).

Considering Brazil's spatial formation phases, Moreira (2014, p. 63) points out that "spatial interaction is a sense that is defined in every specific time, at the production structure level. Every historical time defines its own terms for regionalization and inter-regional relations." For Moreira, the colonial period in Brazil was characterized by the correlation between geoeconomic and geobotanical arrangements, which resulted in five macro-forms of regional characters: the coffee-producing space, the rubber-producing space, the sugarcane planting-producing space, the immigrant colonial space, and the grazing space.

20 As industrialization emerged in 1880 , so did the territorial division of labor, especially after 1950, when national integration takes place and a new qualitative differentiation in industrial concentration develops, in which São Paulo centralized it and took control of the rest of the country. The problematic of regional inequalities emerges from that differentiation caused by industrial, and later financial, concentration-centralization in the South/Southeast regions, especially São Paulo (Moreira, 2014).

21 Although today's relative deindustrialization of São Paulo is leading to new configurations for the territorial division of labor, it does not remove regional inequality. In this context, the spatial matrix of Brazil's geographic organization has been based on the integration of regions in very different development stages, making the country an area with extremely unequal combination, Moreira warns (2014, p. 307). Thus, when looking into the Brazilian sociospatial formation, both oliveira and Moreira point out that identifying regional inequalities in Brazil is only possible from the emergence of the regional division of labor, which came about with the country's industrialization process between 1880 and 1930, and became more intense after 1950 . So focusing on regional imbalances only, even if through a historical analysis of their 
dynamics, does not allow for the complete understanding of the origin and determinants of regional inequalities.

\section{Main Regional Policies in the 20th and 21 st Centuries}

Although some consensus exists in the literature over the moment when regional inequalities became more intense in the country and reached the configuration they have today, as well as over them being included in the government's agenda, identifying the determinants of regional inequalities and the propositions aimed at mitigating them are quite disparate.

Next we will present the major policies established by the Brazilian Federal Government since the mid-20th century in order to politically, economically, and socially impact the sociospatial dynamics that are at the core of the country's regional issue.

\section{Development Poles}

Development Poles in Brazil were created especially in the 1970s and were connected with the idea that having poles of economic production across the space would be a tool to solve growth/development-related problems in "stagnant" regions, based on contributions by authors like Perroux, Myrdal, and Hirschman regarding the Growth Pole Theory (Uderman, 2008a, p. 233). Thus, investing large sums in fixed capital, attracting foreign capital to make industrialization processes feasible, and overseeing and offering State guarantees to reduce international investment risks would be needed (Bomfim, 2007, p. 279, 293).

However, in addition to associating with the industry as a "driving activity," Development Poles in Brazil also covered agricultural and mining projects, usually dedicated to building infrastructure - transportation, communications, and energy (Ibid., p. 275).

These Development Poles were related to territorial policies covered by Brazil's Plan for National Integration (PIN), which strengthened the State's initiatives to promote the creation of a national market and expand the country's economic frontiers from the Southeast-South toward the Center-West, the Amazon, and the Northeast (Costa, 1995, p. 63-64). The PIN was part of the Emilio Medici administration's 1st National Development Plan (1972-1974) and the Ernesto Geisel administration's 2nd National Development Plan (1975-1979). Both plans were clearly based on the "Powerhouse Brazil" ideology, advocated by the Military Dictatorship administrations, in force from 1964 to 1985 . The public policies formulated and implemented in this historical context were highly technocratic, centralizing, and authoritarian, supported by the "developmentalist" State model (Uderman, 2008a, p. 234-238).

Costa (1995, p. 239-240) and Uderman (2008b, p. 111) point out that, instead of reducing regional disparities, the Development Poles actually promoted the concentration of productive investments in the country's most dynamic regions, maintaining, as Bomfim (2007, p. 190) highlights, a center-periphery structure, both in an inter-regional scope and in Brazil's relations with other countries. Additionally, the Development Poles created serious social and environmental problems, demonstrating they were not able to solve Brazil's regional inequality problem (Ablas, 2003, p. 171). 

development theory related to economic polarization, the "developmental" State model was based on the Fordist technical-economic paradigm, which had as a tenet the need to support large industrial projects capable of generating "economies of scale." According to Bomfim (2007, p. 54), the Fordist paradigm was related to a modernization process of the world economy, which in turn was based on capital's spatial expansion and selectivity.

Figure 3 - Cartogram of Development Poles and National Plans for Economic Integration during the Military Dictatorship, 1964-1988

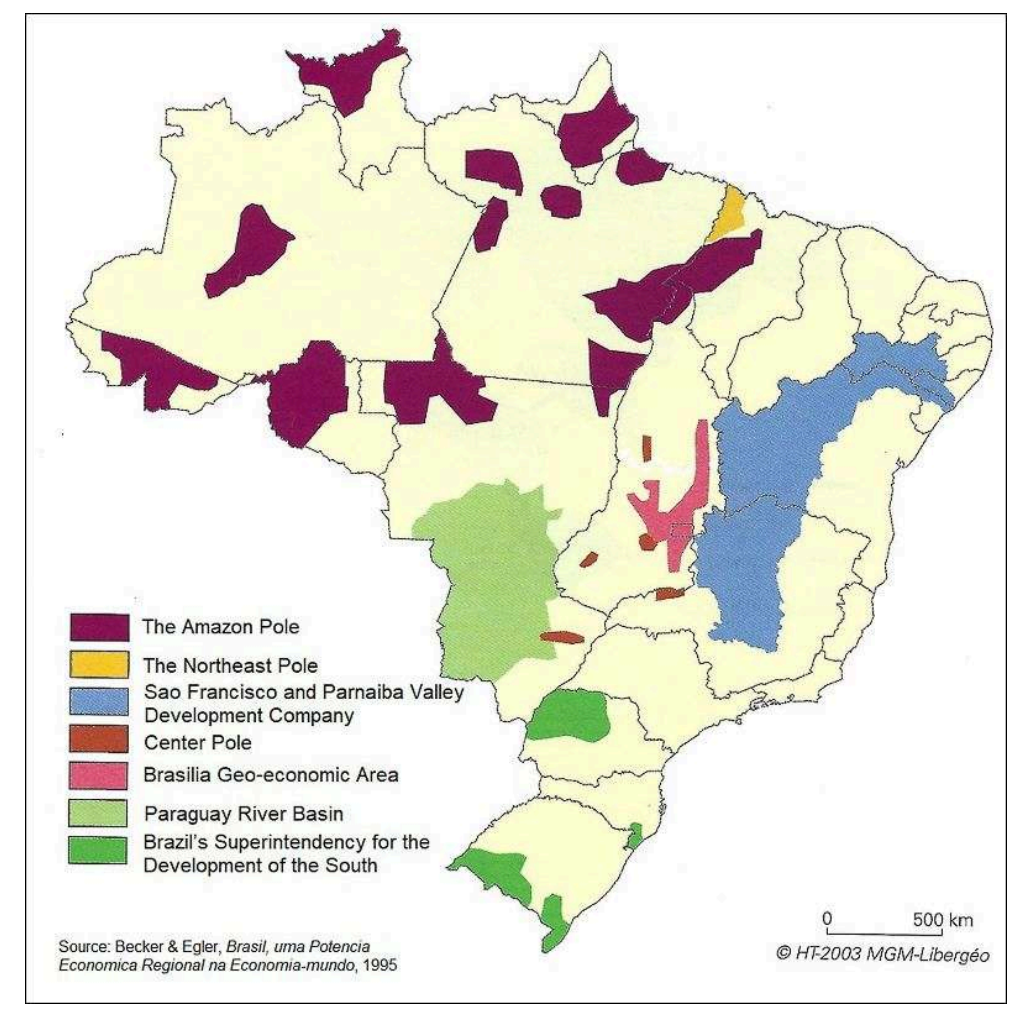

Several programs were created in the 1970s to promote economic development in specific regions: 1971 - Development Program for the Center-West (PRODOESTE); 1972 - Special Program for the São Francisco Valley (PROVALE); 1974 - Agricultural and Agromineral Poles Program for the Amazon (POLAMAZONIA) and Development Program for Integrated Northeastern Areas (POLONORDESTE); 1975 - Development Program for the Cerrados [Brazilian Savannah] (POLOCENTRO); and others.

Source: Théry \& Mello, 2009, p. 269.

\section{National Integration and Development Axes}

Although economic planning techniques have been widely used in Brazil between the 1950 s and 1970s, medium- and long-term national and regional planning were significantly reduced in the 1980s and 1990s due to the State's financial and tax crisis. Nevertheless, Brazil's Federal Government created the National Integration and Development Axes (ENIDs) to guide public and private investment allocation in the scope of the 1996-1999 and 2000-2003 Pluriannual Plans (PPAs).

31 This is a spatial planning policy based on a strong regional development narrative, formulated and implemented in a democratic context during the two Fernando Henrique Cardoso administrations (1995-1998 and 1999-2002). This period was marked 
by public policies with a strong neoliberal character and a managerialist public administration model, introduced in the Brazilian State through an administrative reform ${ }^{2}$ established in 1995 by the FHC administration.

Figure 4 - Cartogram of National Integration and Development Axes in the 1996-1999 PPA

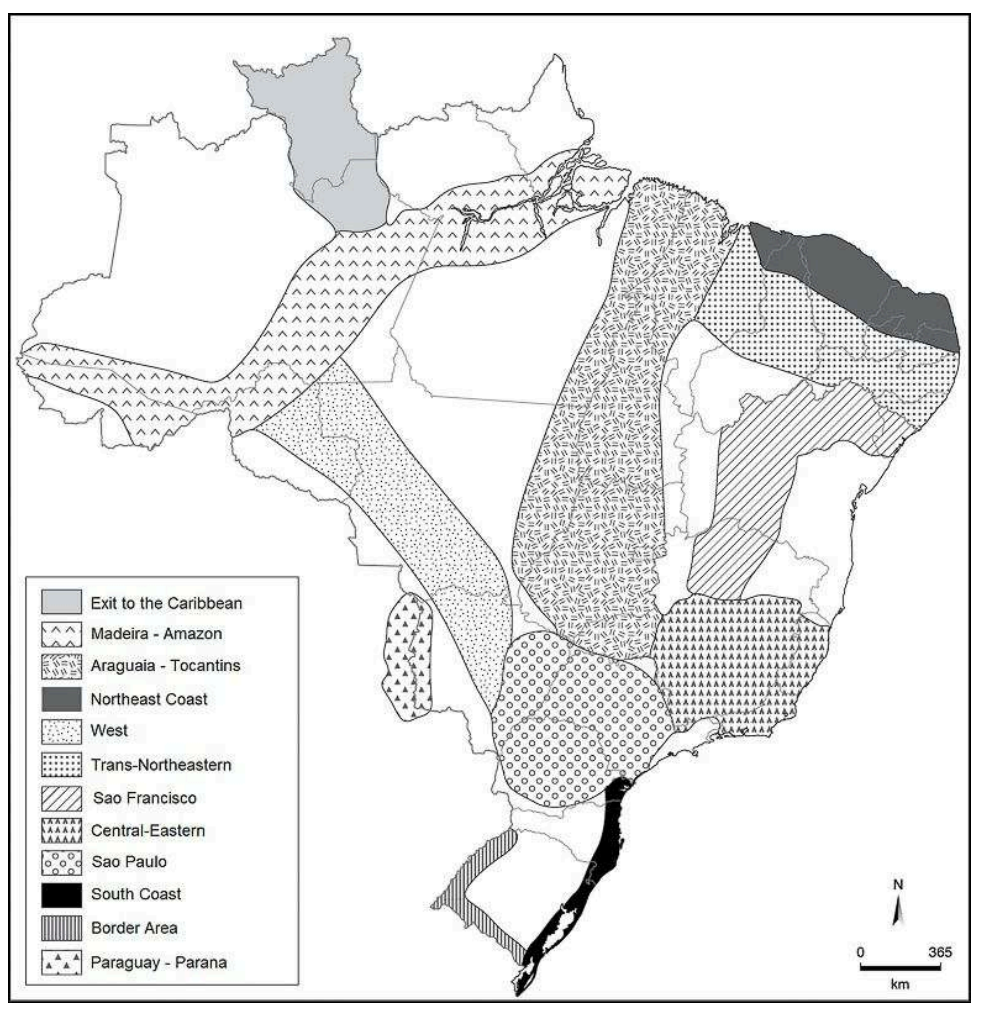

Source: Freitas, 2012, adapted.

The ENIDs would take into account the country's economic geography, especially the flows of goods and services, excluding - for planning purposes - state and regional borders. The infrastructure would then have changed from a geopolitical objective, related to the occupation of territory, to a geoeconomic perspective, in which factors such as natural resources and other potentialities would come after infrastructure as an essential element in the country's economic development (Ablas, 2003, p. 173). Brazil's national territory would be seen as a series of networks, which started to guide national and regional-scale planning, driving investments to selected networks (Thèry \& Mello, 2009, p. 287), as shown in Figure 5. 
Figure 5 - Cartogram of Priority Investments in the 1996-1999 PPA

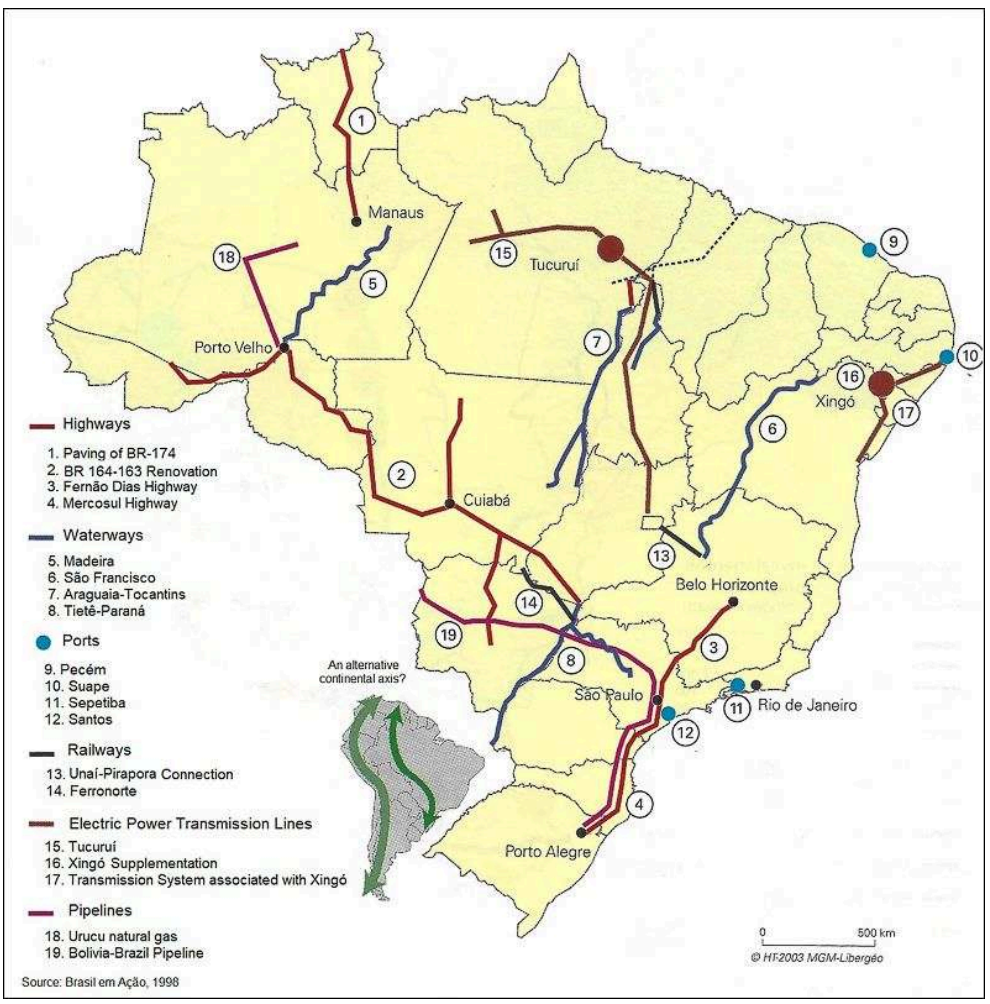

Source: Théry \& Mello, 2009, p. 285.

33 As extensive parts of Brazil's national territory were excluded from the main investment projects, there was heavy criticism of the regional representation used in the 1996-1999 PPA. Consequently, according to Ablas (2003, p. 177), the ENIDs were reviewed, including the respective areas of influence in the axes corresponding to the polarity of communication channels (roads, railways or waterways), according to the urban hierarchy and the functionality of the cities near those channels, as displayed in Figure 6. 
Figure 6 - Cartogram of National Integration and Development Axes in the 2000-2003 PPA

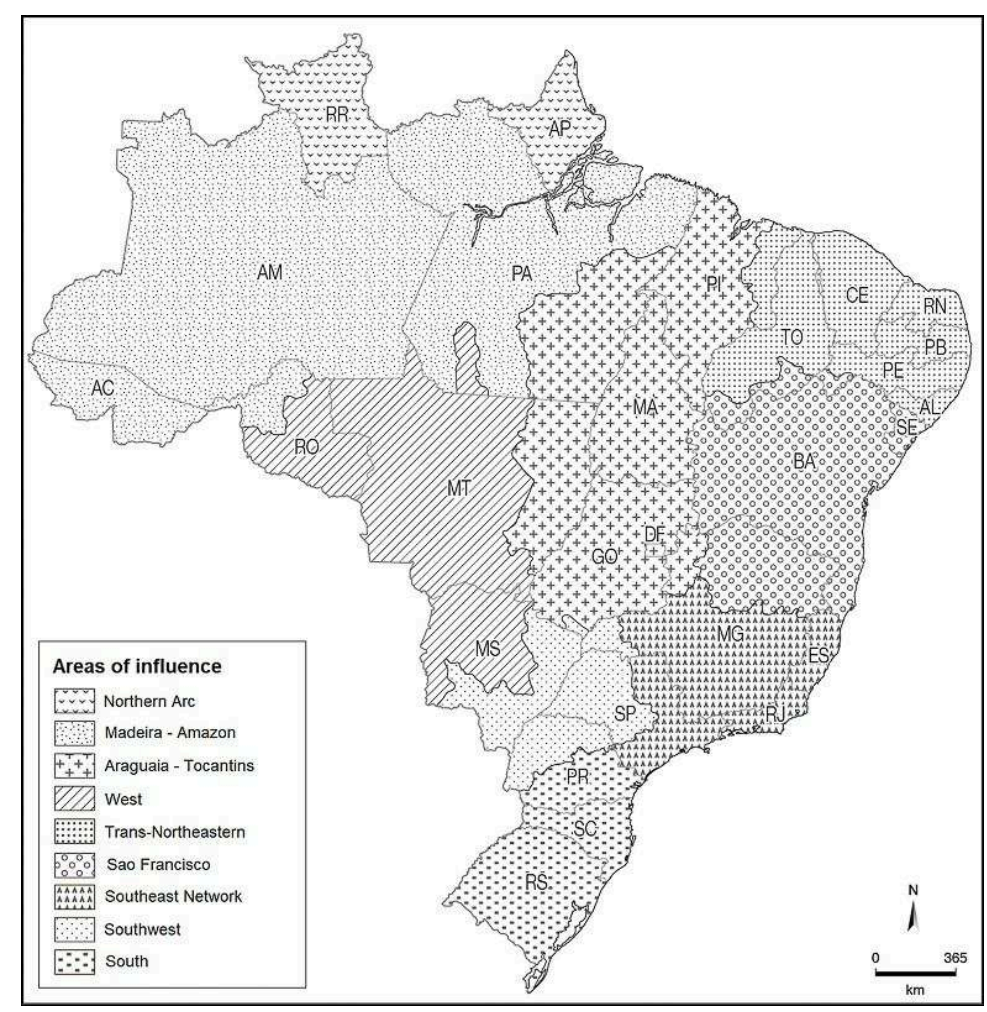

Source: Théry \& Mello, 2009, p. 286, adapted.

34 According to Galvão and Brandão (2003, p. 197-198), even with the axis changes in regions included in the planning, the precedence of communication channels and the policies focused on improving them remained, as top-priority investments shown in Figure 6 demonstrate. This fact led to conceptual inaccuracies and significant variation in the regionalization criteria adopted in the formulation of the ENIDs since their original proposal (Ibid, p. 196). Additionally, the authors highlight that not all axes were actually axes, and this form of regionalization was not enough to cover all actions of a Federal Government Pluriannual Plan. 
Figure 7 - Cartogram of Priority Investments in the 2000-2003 PPA

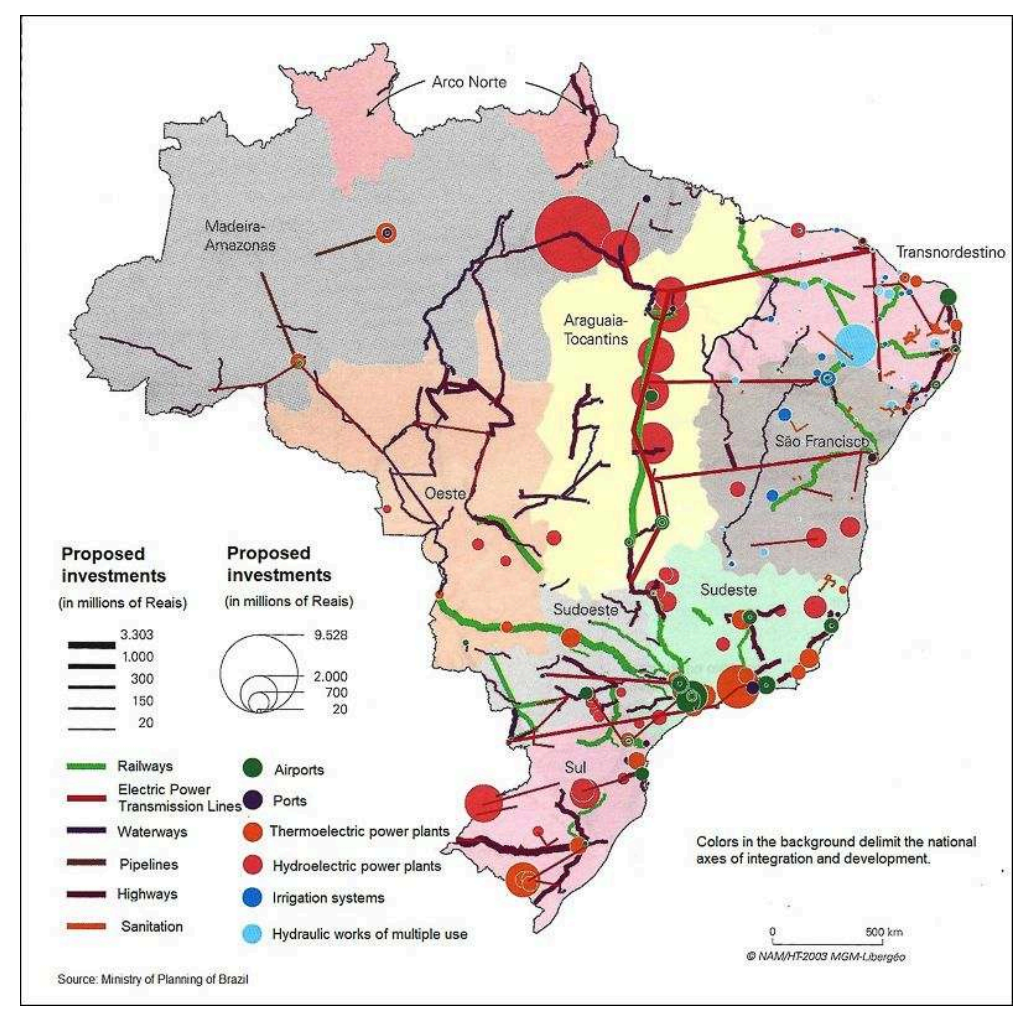

Source: Théry \& Mello, 2009, p. 286.

Through the ENIDs, the 1996-1999 and 2000-2003 Pluriannual Plans concentrated investments in attractive areas, reinforcing regional inequalities and the logic of competition between places (Galvão \& Brandão, 2003, p. 204; Uderman, 2008b, p. 116).

\section{National Policy for Regional Development}

As of 2003, regional planning was resumed with the formulation of the National Policy for Regional Development (PNDR), established by Decree No.6047, of February 22nd, 2007, initially encompassing the years 2008 to $2011^{3}$. This period was marked by the weakening of neoliberalism, as developmentalism gained momentum, based on a more ideological reading according to which the State should recover its intervention ability, as Araújo notes (verbal information) 4 .

The PNDR is different from previous policies because it has several different regional representations and spatial scales, and also because it shifts old political, administrative, and economic paradigms. In this regard, a more complex notion of development stands out, which not only encompassed the economic sphere, but also the social and environmental spheres, as well as the local scale (Silva, 2014, p. 379 et seq.).

Aiming to guide the nature of the policies that would be implemented, the microregions used by the Brazilian Institute of Geography and Statistics (IBGE) were classified by cross-referencing the variables "household income per capita" and "GDP variation per capita," using 1991 and 2000 data. The outcome was the identification of four regional typologies, displayed in Figure 8. 
Figure 8 - PNDR Typology, 2008-2011

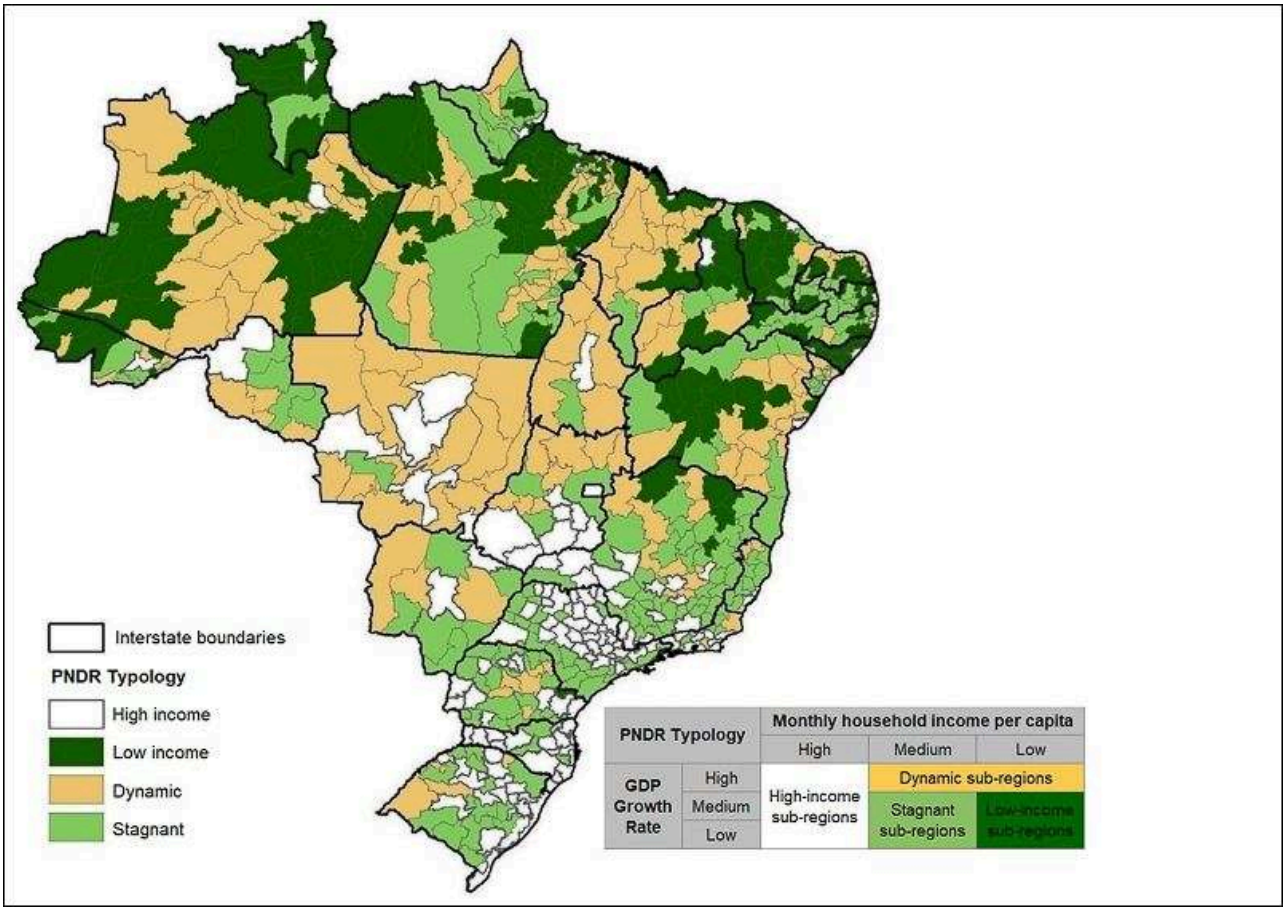

Source: BRAZIL/MI/SDR, 2012, adapted.

However, this typology was little used, as the efforts have focused on the following already existing regional representations: Special Meso-regions, Rural Territories, and Civic Territories, all related to promoting development by boosting social goods and services and encouraging local economic activities. The PNDR defined those regions as top-priority spaces, along with other regional representations, as displayed in Figure 8. 


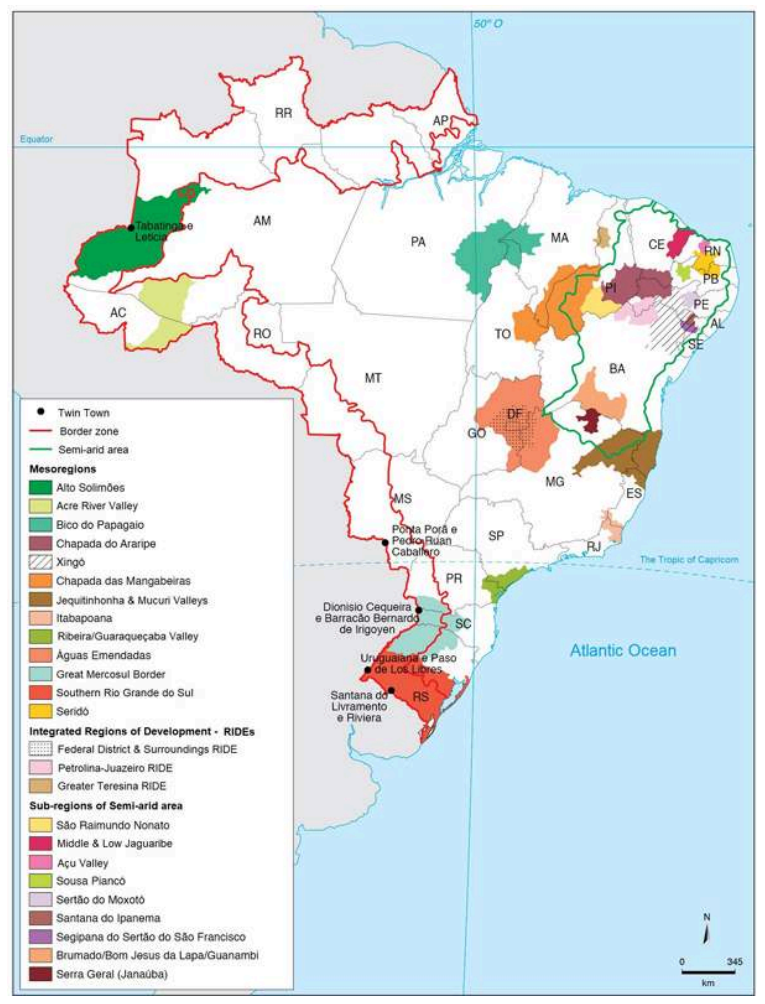

Source: BRAZIL/MI/SDR, 2012, adapted.

Similar to Development Poles and ENIDs, the PNDR had very scant implications for overcoming the regional inequalities that pervade the Brazilian sociospatial landscape.

Let it be noted that essentially regional policies are credited to the Ministry of National Integration. Nevertheless, Civic Territories and Rural Territories - i.e., two of the three government programs that received the most political attention from the PNDR reported to Brazil's Ministry of Agricultural Development and hence had a more specific approach. Moreover, tax incentives created by the PNDR remained focused on large private enterprises, which tend to increase the historical social and spatial concentration of the country's wealth. So this policy's most innovative proposals had low levels of implementation, greatly reducing the promotion of Local Production Arrangements, which are more diverse and exert limited impact on regional and national contexts.

\section{Divergent Readings and Action Proposals: The Regional Problematic at the Core of Brazil's (Under)Development}

The reading on the origin of regional inequalities is closely related to the identification of their determining elements and, therefore, to the character of proposals, academic or governmental alike, aimed at overcoming them. It is imperative to note that these readings and intervention proposals for the sociospatial dynamics, including the regional problematic, have their own set of underlying ideologies and political projects, 
which may have a higher or lower degree of adherence to the purposes of hegemonic players in power.

Understanding regional inequalities as imbalances/disparities in the economic growth rates of the country's different areas, like Celso Furtado and Wilson Cano do, suggests proposals that intend to promote economic dynamism in "backward"/"stagnant" regions. From a government viewpoint, this acceptation was partly used to subsidize the creation of Development Poles in the 1970s, which were carried out in a politically and spatially centralized manner, as well as bureaucratic, disconnected from other public policies, and with no social participation, thus resulting in increasing regional inequalities in Brazil.

Understanding the country's regional inequalities as a consequence of its regional division of labor at the national level, resulting from the process of industrialization, as Francisco de Oliveira and Ruy Moreira do, tends to imply proposals related to a spatial (re)planning, as they aim at changing the socioeconomic structure of the country's territory, including inter-regional relations, involving developed/central/advanced regions and underdeveloped/peripheral/backward regions. In this regard, so far there have been no public policies aiming at a true regional (re)planning in Brazil, even though our Federal Constitution, enacted in 1988, stipulates it is imperative to adopt such a policy in the scope of a National Project, which, incidentally, is also nonexistent. The National Integration and Development Axes, with a purpose that is similar to a territorial (re)planning policy, at their core actually increased existing regional inequalities. This fact is partly associated with neoliberal influences entrenched in the political-economic realm, and with managerialist influences in the politicaladministrative realm.

Considering the essence of the National Policy for Regional Development, we consider it would have greater ability to fight regional inequality, given its set of theoretical and methodological innovations and new financial and administrative instruments, like the National Fund for Regional Development. However, the political resistance that emerged against the PNDR, as it had potential to contribute with the structural change necessary to the country's socioeconomic development, ended up leading to serious implementation and execution deficits (Silva, 2014).

This shows that the regional problematic is at the core of Brazil's underdevelopment, because it is in line with our "structural malformation," as Furtado points out (2013, p. 27). Nevertheless, in order to build a more egalitarian country, consensus must exist over the scope of a long-term national project regarding the regional problematic.

\section{BIBLIOGRAPHY}

Ablas L., 2003. O "Estudo dos Eixos" como instrumento de planejamento regional. In Gonçalves M. F., Brandão C. A., Galvão A. C. F. (Orgs.), Regiões e cidades, cidades nas regiões: o desafio urbanoregional. São Paulo, Editora Unesp/Anpur, p. 171-186. 
Araújo T., 2007. Bacelar de. Brasil: desafios de uma Política Nacional de Desenvolvimento Regional contemporânea. In Diniz C. C. (Org.), Políticas de desenvolvimento regional: desafiose perspectivas à luz das experiências da União Européia e do Brasil. Brasilia, Editora da Universidade de Brasília, p. 221-236.

Brandão C., 2007. Território e desenvolvimento: as múltiplas escalas entre o local e o global. Campinas, Editora da Unicamp.

Brandão C., 2013. Preface. In D'Aguiar R. F. (Org.). Essencial Celso Furtado. São Paulo, Penguin Classics Companhia das Letras, p. 19-31, 1st. ed.

BRAZIL. Ministry of National Integration-MI, Regional Development Office-SDR, 2012. I National Conference on Regional Development. Reference Text. Brasilia, BRAZIL/MI/SDR.

BRAZIL. Ministry of Agrarian Development-MDA, Territorial Development Office-SDT, 2010. Balanço de Gestão: Resultados das ações do Programa Desenvolvimento Sustentável de Territórios Rurais (PRONAT) 2003-2010. Brasilia, BRAZIL/MDA/SDT.

Bomfim P. R. A., 2007. A ostentação estatística (um projeto geopolítico para o território nacional: estado e planejamento no período pós-64. Dissertation (Doctoral Degree in Geography), Faculty of Philosophy, Languages and Literature, and Human Sciences, University of São Paulo, São Paulo.

Cano W., 2002. Ensaios sobre a formação regional econômica do Brasil. Campinas, Editora da Unicamp.

Cano W., 2007. Desequilíbrios regionais e concentração industrial no Brasil 1930-1970. São Paulo, Editora Unesp, 3rd ed.

Cano W., 2008. Desconcentração produtiva regional no Brasil 1970-2010. São Paulo, Editora Unesp, 3rd ed.

Cano W., Guimarães Neto L., 1986. A questão regional no Brasil: traços gerais e sua evolução histórica. Revista de Economia Política, n 10, Jul./Dec. 1986, p. 167-184.

Costa W. M. da., 1995. O Estado e as políticas territoriais no Brasil. 4th ed., São Paulo, Contexto.

Freitas W. D. de., 2012. O planejamento regional brasileiro no fim do século XX: os eixos nacionais de integração e desenvolvimento. Revista Territorial, vol. 1, n 1, p. 47-72.

Furtado C., 2009a. A Operação Nordeste. In Furtado C., O Nordeste e a Saga da Sudene. Rio de Janeiro, Contraponto, p. 29-71.

Furtado C., 2009b. Discurso de posse na Sudene. In Furtado C., O Nordeste e a Saga da Sudene. Rio de Janeiro, Contraponto, p. 165-170.

Furtado C., 2009c. Uma política de desenvolvimento econômico para o Nordeste. In Furtado C., $O$ Nordeste e a Saga da Sudene. Rio de Janeiro, Contraponto, p. 83-164.

Furtado C., 2014. A Fantasia Desfeita. In Furtado C., Obra autobiográfica. São Paulo: Companhia das Letras, p. 207-398, 1st ed.

Galvão A. C. F., Brandão C. A., 2003. Fundamentos, motivações e limitações da proposta governamental dos "Eixos Nacionais de Integração e Desenvolvimento". In Gonçalves M. F., Brandão C. A., Galvão A. C. F. (Orgs.), Regiões e cidades, cidades nas regiões: o desafio urbano-regional. São Paulo, Editora Unesp/Anpur, p. 187-224.

Instituto Brasileiro De Geografia E Estatística -IBGE, 2003. O Brasil do Século XX - Entrevista com Celso Furtado. In IBGE, Estatísticas do Século XX. Rio de Janeiro, IBGE, p. 11-24.

Menezes A. S. B. de, Filho J. S., 2009. O GTDN e as exigências da atualidade. Entrevista com Celso Furtado. In: Furtado C., O Nordeste e a Saga da Sudene. Rio de Janeiro, Contraponto, p. 267-283. 
Moreira R., 2008. Noiva da revolução; Elegia para uma re(li)gião: Sudene, Nordeste. Planejamento e conflito de classes. São Paulo, Boitempo.

Moreira R., 2014. A formação espacial brasileira: contribuição crítica aos fundamentos espaciais da geografia do Brasil. Rio de Janeiro, Consequência, 2nd ed.

Oliveira F. de., 2003. Crítica à razão dualista; O ornitorrinco. São Paulo, Boitempo.

Oliveira F. de., 2008. Noiva da revolução; Elegia para uma re(li)gião: Sudene, Nordeste. Planejamento e conflito de classes. São Paulo, Boitempo.

Silva S. A. da., 2014. O planejamento regional brasileiro pós-constituição federal de 1988: instituições, politicas e atores. Thesis (Master's Degree in Human Geography) - Faculty of Philosophy, Languages and Literature, and Human Sciences, University of São Paulo, São Paulo.

Théry H., Mello N. A. de., 2009. Atlas do Brasil: disparidades e dinâmicas do território. $2^{\text {nd }}$ ed., São Paulo, Editora da Universidade de São Paulo.

Uderman S, 2008a. O Estado e a formulação de políticas de desenvolvimento regional. Revista Econômica do Nordeste, Fortaleza, vol. 39, n² 2, p. 232-250, Apr/Jun.

Uderman S, 2008b. Políticas de Desenvolvimento Regional no Brasil: limites de uma nova agenda para o Nordeste. Associação Brasileira de estudos regionais e urbanos, vol. 2, nº 2, p. 104-112.

\section{NOTES}

1. The Economic Commission for Latin America (ECLAC) is one of the United Nations' five regional branches and its headquarters are in Santiago, Chile. Celso Furtado was one of its most prominent members. For more information, see: http://www.cepal.org/en/about

2. The Master Reform Plan for the State Apparatus (PDRAE) was based on two assumptions: the crisis of the State and the lack of governance. The goal with the PDRAE was to reduce State apparatus and limit its actions to strategic roles. This way, the State would go from "entrepreneur" and "interventionist" to "regulatory" by adopting a managerial administration. This was mainly based on the notions of: decentralization, rationalization, governance, resultsbased control, privatization, publicization, flexibilization, marketization, accountability, clientcitizen orientation, competition between agencies and between the agencies and private institutions and/or civil society organizations, as well as values such as efficiency and effectiveness. See: BRAZIL. Ministry of Federal Administration and State Reform (MARE). Plano Diretor de Reforma do Aparelho do Estado. Brasilia, Brazil/Mare, 1995.

3. There is a Bill in Brazil's Congress aimed at consolidating the PNDR as a long-term strategic policy.

4. Information provided by Tânia Bacelar de Araújo in an interview with the author on Dec/5/13.

\section{ABSTRACTS}

This article presents divergent readings on the origin of regional inequalities in Brazil by four scholars: Celso Furtado, Wilson Cano, Francisco de Oliveira, and Ruy Moreira. Moreover, it 
discusses the essence of major policies established by the Brazilian Federal Government since the mid-20th century in order to politically, economically, and socially impact the sociospatial dynamics that are at the core of the regional issue. In this sense, Development Poles, National Integration and Development Axes, and the National Policy for Regional Development stand out. Each reading and intervention proposal for the regional problematic has its own set of underlying ideologies and political projects, which may have a higher or lower degree of adherence to the purposes of hegemonic players in power, or that are appropriated by them. Therefore, elucidating the essence and the consequences of those divergent readings and proposed actions regarding the regional problematic is vital in order to understand the role of regional inequalities in Brazil's socioeconomic development landscape.

Cet article porte sur la divergence des lectures sur l'origine des inégalités régionales au Brésil, sous l'interprétation de quatre intellectuels: Celso Furtado, Wilson Cano, Francisco de Oliveira et Ruy Moreira. En outre, l'article traite de l'essence des principales politiques créées par le gouvernement fédéral brésilien depuis le milieu du $\mathrm{XX}^{\mathrm{e}}$ siècle afin d'intervenir sur le plan politique, économique et social dans les dynamiques socio-spatiales au cœur des questions régionales. Dans ce cas, nous mettons en évidence les Pôles de développement, les Axes nationaux d'intégration et de développement et la Politique nationale pour le développement régional. Les lectures et propositions d'intervention dans les questions régionales portent des idéologies et des projets politiques sous-jacents qui sont plus ou moins cohérents avec les objectifs des acteurs hégémoniques au pouvoir ou qui sont appropriés par ceux-ci. Par conséquent, il est essentiel d'élucider l'essence et les implications de ces lectures et propositions d'action concernant la problématique régionale afin de comprendre le rôle des inégalités régionales dans le panorama du développement socio-économique au Brésil.

\section{INDEX}

Mots-clés: inégalité régionale, question régionale, Brésil, pôle de développement, Axes nationaux d'intégration et de développement (Enids), Politique nationale pour le développement régional (PNDR)

Keywords: Regional Inequalities, Regional Issue, Brazil, Development Pole, National Integration and Development Axes (ENIDs), National Policy for Regional Development (PNDR)

\section{AUTHOR}

\section{SIMONE AFFONSO DA SILVA}

Simone Affonso da Silva, simone.affonso.silva@gmail.com, is Doctorate Student at the Human Geography Postgraduate Program of the Faculty of Philosophy, Languages and Literature, and Human Sciences of the University of Sao Paulo. 